\title{
PENGETAHUAN TERHADAP KEIKUTSERTAAN IBU HAMIL MELAKUKAN SCREENING HIV/AIDS
}

\author{
Frisca Dewi Yunadi ${ }^{1}$, Rochany Septiyaningsih ${ }^{2}$ \\ Institusi/afiliasi penulisSTIKES Al Irsyad Al Islamiyyah Cilacap ${ }^{1,2}$ \\ e-mail: friscadewiyunadi@gmail.com ${ }^{l}$
}

\begin{abstract}
HIV or Human Immunodeficiency Virus is a disease that can attack the human immune system, including pregnant women. HIV / AIDS screening for pregnant women is an effort to open access to HIV / AIDS status for pregnant women. The hope is that all pregnant women, both positive and negative, can find out and prevent early prevention, namely the transmission of HIV / AIDS to their children. This is to determine the relationship between knowledge and the participation of pregnant women in screening for HIV / AIDS. The subjects in this study were 30 pregnant women who were in the working area of Puskesmas Cilacap Selatan 1. The method of this research was observational analytic using cross sectional method. The subjects of this study were 30 pregnant women in the area of Puskesmas Cilacap Selatan 1. The research instrument used a questionnaire. Based on the results of the chi square statistical test, it showed that there was no significant relationship between knowledge and the participation of pregnant women in HIV / AIDS screening $(p=0.001<\alpha=0.05)$
\end{abstract}

Keywords: knowledge, screening, HIV / AIDS

\begin{abstract}
ABSTRAK
HIV atau Human Immunodeficiency Virus adalah penyakit yang dapatmenyerang sistem kekebalan manusia termasuk ibu hamil. Skrining HIV/AIDS pada ibu hamil adalah upaya membuka akses untuk mengetahui status HIV/AIDS bagi ibu hamil, harapannya seluruh ibu hamil baik yang berstatus positif ataupun negatif dapat mengetahui serta upaya pencegahan lebih dini yaitu penularan HIV/AIDS kepada anak yang dikandungnya.Tujuan penelitian ini untuk mengetahui hubungan antara pengetahuan dengan keikutsertaan ibu hamil melakukan screening HIV/AIDS. Subyek dalam penelitian ini adalah 30 ibu hamil yang berada di Wilayah kerja Puskesmas Cilacap Selatan 1. Metode penelitian ini adalah observasional analitik dengan menggunakan metode cross sectional. Subyek penelitian ini adalah 30 ibu hamil di wilayah Puskesmas Cilacap Selatan 1. Instrumen penelitian ini menggunakan kuesioner. Berdasarkan hasil uji statistik chi square menunjukkan tada hubungan yang bermakna antara pengetahuan dengan keikutsertaan ibu hamil melakukan screening HIV/AIDS $(\mathrm{p}=0,001<\alpha=0,05)$
\end{abstract}

Kata kunci: pengetahuan, screening, HIV/AIDS

\section{PENDAHULUAN}

\section{Latar Belakang}

HIV atau Human Immunodeficiency Virus adalah penyakit yang dapatmenyerang sistem kekebalan manusia. HIV dapat menyerang semua orang dari semua kelompok usia tidak terkecuali ibu hamil. Jumlah ibu hamil yang terinfeksi HIV (Humman Immunodeficiency Virus) dari tahun ke tahun semakin meningkat, seiring dengan meningkatnya jumlah laki-laki yang melakukan hubungan seksual tidak aman, yang selanjutnya akan menularkan pada pasangan seksualnya yang akan berdampak pada bayi yang dikandung ibu hamil sebab penularan HIV dari ibu ke bayi merupakan akhir dari rantai penularan HIV. Penularan HIV dari ibu ke bayi mencapai hingga $90 \%$ kasus $^{1}$.

Prosentasi HIV di Indonesia paling banyak ditemukan kasus pada kelompok umur 25-49 tahun
$(69,7 \%)$ dan pada kasus AIDS tertinggi adalah kelompok umur 30-39 tahun (37,7\%). Berdasarkan data tersebut terlihat bahwa kelompok umur yang paling berisiko terhadap penularan HIV dan kejadian AIDS adalah kelompok umur produktif yaitu rentang umur 20-39 tahun ${ }^{2}$.

Data hasil kegiatan dari Kemenkes RI tahun 2015 menunjukkan dari 43.264 ibu hamil yang menjalani tes HIV, $1.329 \quad(3,04 \%)$ positif terinfeksi.Pada tahun 2016, jumlah keseluruhan penderita HIV di Indonesia adalah 150.285 dan AIDS 55.799. ${ }^{2}$

Menurut data Kemenkes, dari tahun 20052015,data ibu hamil didapatkan sebanyak 5.290.235 orang dan dari jumlah tersebut ibu hamil yang sudah melakuka skrinning HIV/AIDS sebanyak 30.526 pada tahun 2015. Terdapat kasus HIV/ AIDS sebanyak 184.929 yang didapat dari layanan konseling dan tes HIV/ AIDS. $^{2}$ 
tahun 2016, dari angka tersebut maka diperkirakan kebutuhan layanan Pencegahan Penularan HIV dari Ibu ke bayinya (PPIA) juga akan meningkat dari 13.189 orang di tahun 2012 menjadi 16.191 orang pada tahun 2016. Demikian pula jumlah anak berusia dibawah 15 tahun yang tertular HIV dari ibunya pada saat dilahirkan atau saat menyusui akan meningkat dari 4.361 (2012) menjadi 5.565 (2016). Tingginya jumlah kasus HIV/AIDS berdampak terhadap populasi umum, seperti ibu hamil sehingga meningkatnya risiko penularan dari ibu ke bayi. Berdasarkan data yang di dapatkan tahun 2018 ibu hamil yang menderita HIV/AIDS di Kabupaten Cilacap mencapai 4 kasus, 4 orang telah melahirkan, 4 bayi terbukti positif dari $\mathrm{HIV}^{3}$.

Penyakit HIV/AIDS merupakan salah satu penyakit menular yang dikelompokkan sebagai salahsatu faktor penyebab kematian ibu dan anak. Salah satu upaya untuk mencegah secara dini penyakit HIV/ AIDS pada ibu hamil adalahdengancara melakukanskrining HIV/ AIDS.Halini dimaksudkan agar ibu hamil mengetahui secara dini HIV/AIDS dan apabila ibu hamil tersebut positif HIV/AIDS, memungkinkan ibu untuk dipantau secara medis dan mendapatkan terapi yang tepat

Berdasarkan Keputusan Menteri Kesehatan Nomor 1507/Menkes/SK/X/2005 tentang Konseling dan Testing HIV/AIDS Secara Sukarela (Voluntary Counseling And Testing) (Kemenkes, 2013 nomor 51). Maka semua ibu hamil diwajibkanuntuk melakukan skrinning HIV/ AIDS

Skrining HIV/AIDS pada ibu hamil adalah upaya membuka akses untuk mengetahui status HIV/AIDS bagi ibu hamil, harapannya seluruh ibu hamil baik yang berstatus positif ataupun negatif dapat mengetahui serta upaya pencegahan lebih dini yaitu penularan HIV/AIDS kepada anak yang

\section{Tujuan Penelitian}

\section{Tujuan Umum}

Untuk mengetahui adakah hubungan Pengetahuan terhadap keikutsertaan ibu hamil melakukan Screening HIV/ AIDS

\section{Tujuan Khusus}

a. Mengetahui distribusi frekuensi tingkat pengetahuan ibu hamil tentang HIV/AIDS

b. Mengetahui distribusi frekuensi keikutsertaan ibu hamil dalam melakukan screening HIV/AIDS

c. Mengetahui hubungan Pengetahuan terhadap keikutsertaan ibu hamil melakukan Screening HIV/ AIDS. dikandungnya, memperoleh pengobatan sedini mungkin informasi, pengetahuan dan dukungan psikologis tentang HIV/AIDS ${ }^{1}$.

Tujuan utama dari skrining HIV/AIDS pada ibu hamil ini sesuai dengan UU No. 51 tahun 2013 tentang pedoman pencegahan penularan HIV dari ibu ke anak yaitu penanggulangan HIV dan AIDS untuk menurunkan kasus HIV serendah mungkin dengan menurunnya jumlah infeksi HIV baru, mengurangi stigma dan diskriminasi, serta menurunnya kematian akibat AIDS (Getting to Zero) dengan melakukan peningkatan komitmen dari berbagai pihak dan masyarakat dalam pelaksanaan skrining HIV/AIDS untuk pencegahan penularan HIV dari ibu ke anak.

Pada pemeriksaan Antenatal Care (ANC) Terpadu didalamnya termasuk pemeriksaan skrining HIV/AIDS yang dilakukan oleh bidan ataupun petugas kesehatan yang bisa dilaksanakan di Puskesmas. Puskesmas merupakan pusat kesehatan masyarakat dan fasilitas tingkat pertama yang keberadaannya sangat penting di masyarakat. Untuk di wilayah Puskesmas Cilacap Selatan 1 sendiri, seluruh ibu hamil yang terdata biasanya akan mendapatkan undangan untuk melakukan pemeriksaan ANC Terpadu termasuk skrining HIV/AIDS. Namun, tidak semua ibu hamil bersedia untuk melakukan skrining HIV/AIDS dengan beberapa alasan antara lain karena merasa tidak tertular HIV/AIDS dan juga rendahnya pengetahuan ibu hamil tentang HIV/AIDS dan penularannya ke anak.

Hal inilah yang mendasari peneliti untuk melakukan peneitian Pengetahuan terhadap keikutsertaan ibu hamil melakukan Screening HIV/ AIDS di Puskesmas Cilacap Selatan 1 Kabupaten Cilacap

\section{METODE}

Penelitian ini merupakan penelitian studi analitik observassiaonal dengan pendekatan cross sectional. Penelitian dilakukan di wilayah Puskesmas Cilacap Selatan 1 Kabupaten CIlacap. Populasi dalam penelitian ini adalah semua ibu hamil pada tahun 2020 di Wilayah Puskesmas Cilacap Selatan 1. Sampel yang digunakan dalam penelitian ini purposive sampel sebanyak $30 \mathrm{ibu}$ hamil. Analisis data yang dilakukan meliputi analisa univariat dan bivariat dengan uji chi square. 


\section{HASIL}

\section{Analisis Univariat}

Tabel 1.

Distribusi Responden Berdasarkan Tingkat Pengetahuan Ibu Hamil Tentang HIV/AIDS Di Wilayah Puskesmas Cilacap Selatan 1 Tahun 2020

\begin{tabular}{|c|c|c|}
\hline $\begin{array}{c}\text { Pengetahuan Ibu Hamil } \\
\text { Tentang HIV/AIDS }\end{array}$ & Jumlah & Prosentase \\
\hline Kurang & 12 & $40 \%$ \\
\hline Sedang & 5 & $10 \%$ \\
\hline Baik & 15 & $50 \%$ \\
\hline Jumlah & 30 & $100 \%$ \\
\hline
\end{tabular}

Sumber : Data Primer, 2020

Berdasarkan Tabel 1 dapat dilihat bahwa Sebagian besar (50\%) ibu Hamil memiliki pengetahuan yang Baik tentang HIV/AIDS.

Tabel 2.

Distribusi Responden Berdasarkan Keikutsrtaan Ibu Hamil Melakukan Screening HIV/AIDS Di Wilayah Puskesmas Cilacap Selatan 1 Tahun 2020

\begin{tabular}{|c|c|c|}
\hline $\begin{array}{c}\text { Keikutsertaan Ibu } \\
\text { Hamil Melakukan } \\
\text { Screening HIV/AIDS }\end{array}$ & Jumlah & Prosentase \\
\hline Ya & 16 & $53 \%$ \\
\hline Tidak & 14 & $47 \%$ \\
\hline Jumlah & 30 & $100 \%$ \\
\hline
\end{tabular}

Sumber : Data Primer, 2020

Berdasarkan Tabel 2 dapat dilihat bahwa Sebagian besar (53\%) ibu Hamil sudah melakukan screening HIV/AIDS.

\section{Analisis Bivariat}

Tabel 3.

Distribusi Responden Berdasarkan Karakteristik Ibu Hamil Di Wilayah Puskesmas

Cilacap Selatan 1 Tahun 2020

\begin{tabular}{|l|c|c|}
\hline Karakteristik & Frekuensi & Prosentase \\
\hline Usia & \\
\hline $\begin{array}{l}\text { Reproduksi Sehat } \\
(20-35 \text { tahun) }\end{array}$ & 26 & $86 \%$ \\
\hline $\begin{array}{l}\text { Beresiko (>20 } \\
\text { tahun dan >35 } \\
\text { tahun }\end{array}$ & 4 & $14 \%$ \\
\hline Pendidikan & \\
\hline Dasar & 9 & $30 \%$ \\
\hline Menengah & 21 & $70 \%$ \\
\hline Tinggi & 0 & $0 \%$ \\
\hline Paritas & 14 & $47 \%$ \\
\hline Primipara & 16 & $53 \%$ \\
\hline Multipara & \\
\hline
\end{tabular}

Berdasarkan Tabel 3 dapat dilihat bahwa mayoritas ibu hamil dalam katagorei reproduksi sehat yaitu sebanyak 86\%. Pada karakteristik Pendidikan Sebagian besar dalam katagori Pendidikan Menengah yaitu $70 \%$ dan Sebagian besar paritas ibu hamil yaitu multiparitas sebesar 53\%.

Tabel 4.

Analisa Bivariat Hubungan Pegetahuan dengan Keikutsrtaan Ibu Hamil Melakukan Screening HIV/AIDS Di Wilayah Puskesmas

\begin{tabular}{|c|c|c|c|c|c|}
\hline \multirow{3}{*}{$\begin{array}{c}\text { Variabel } \\
\text { Independen }\end{array}$} & \multicolumn{4}{|c|}{ Keikutsertaan Ibu } & \multirow[t]{3}{*}{$\mathrm{P}$} \\
\hline & \multicolumn{2}{|c|}{$\mathrm{Ya}$} & \multicolumn{2}{|c|}{ Tidak } & \\
\hline & $\mathrm{n}$ & $\%$ & $\mathrm{n}$ & $\%$ & \\
\hline \multicolumn{6}{|l|}{ Pengetahuan } \\
\hline Kurang & 1 & 9 & 11 & 91 & 0.001 \\
\hline Sedang & 4 & 89 & 1 & 10 & \\
\hline Baik & 11 & 92 & 1 & 8 & \\
\hline
\end{tabular}

Sumber : Data Primer yang diolah, 2020

Berdasarkan table 4 uji Chi square di SPSS dapat diketahui pada uji Person Chi-Square adalah sebesar 0,001. Karena nilai Asymp.Sign $0,000<0,05$, maka dapat disimpulkan bahwa ada hubungan antara pengetahuan ibu hamil dengan keikutsertaan ibu hamil mengikuti screening HIV/AIDS DI Wilayah Puskesmas Cilacap Selatan 1. Hal ini dapat diartikan pula bawha semakin tinggi pengetahuan maka ibu hamil akan cendrung untuk mengikuti screening HIV/AIDS. 


\section{PEMBAHASAN}

Hasil penelitan menunjukkan ada hubungan antara pengetahuan ibu hamil tentang HIV/AIDS terhadap keikutsertaan ibu hamil melakukan screening HIV/AIDS. Hal ini didukung oleh penelitian Titik (2011) yang menyatakan bahwa terdapat hubungan antara pengetahuan ibu hamil tentang HIV/AIDS dan VCT dengan sikap terhadap konseling dan tes HIV/AIDS secara sukarela di Puskesmas Karangdoro Semarang dengan hasil penelitian didapatkan adalah nilai $\mathrm{p}$-value $<0,05 .{ }^{4}$

Tingkat pengetahuan ibu hamil mengenai HIV/AIDS di wilayah kerja Puskesmas Cilacap Selatan 1 sebanyak $50 \%$ dalam katagori baik. Notoatmojdo (2012) mengatakan bahwa pengetahuan adalah hasil dari tahu ini yang terjadi setelah orang melakukan penginderaan terhadap suatu obyek tertentu. ${ }^{5}$ Pengetahuan adalah hasil mengingat suatu hal, termasuk mengingat kembali kejadian yang pernah dialami baik secara sengaja maupun tidak disengaja dan ini terjadi setelah orang melakukan kontak atau pengamatan terhadap suatu objek tertentu ${ }^{6}$.

Faktor yang mempengaruhi pengetahuan seseorang menurut Mubarak, 2011 antara lain adalah usia, pendidikan, pekerjaan, minat, pengelaman, lingkungan dan informasi. Usia seseorang dapat dihutung dari dilahirkannya orang sampai berulang tahun yang terakhir. Umur biasanya juga berpengaruh terhadap kematangan, daya pikir serta pola pikir orang. Biasanya, dengan bertambahnya usia seseorang maka berkembang pula kematangan dan daya pikirnya sehingga pengetahuannya pun semakin meningkat ${ }^{7}$. Pada usia 20-35 tahun menurut Hurlock (2012) disebut juga masa dewasa,dimana pada masa ini diharapkan masalah-masalah yang dihadapi dengan tenang secara emosional, terutama dalam menghadapi kehamilan, persalinan dan merawat bayi. Pada masa ini seseorang akanlebih perperan aktif dalam masyarakat dan sosial ${ }^{6}$

Tingkat pengetahuan ibu hamil yang baik tentang HIV/AIDS dipengaruhi oleh faktor umur responden mayoritas berusia 20-35 tahun sebanyak $86 \%$. Penelitian ini didukung dengan hasil dari penelitian Othman (2015) yang menunjukkan adanya hubungan yang signifikan antara pengetahuan tentang HIV/AIDS dengan usia yang lebih matang dengan nilai $\mathrm{p}=0.005$. $^{8}$

Pendidikan adalah suatu bimbingan yang diberikan seseorang kepada orang lain agar dapat memahami sesuatu hal. Pendidikan sebagai pengembangan kepribadian dan kemampuan didalam maupun diluar sekolah dan berlansung seumur hidup. Pendidikan sangat berpengaruh dengan proses belajar seseorang, semakin tinggi pendidikan seseorang semakin mudah pula orang tersebut memperoleh informasi. Baik dari orang lain maupun media masa. Semakin banyak informasi tentang kesehatan yang diperoleh maka semakin banyak pula pengetahuan yang didapat. Pengetahuan yang baik sangat mempengaruhi pola pikir seseorang, karena semakin tinggi pengetahuan seseorang semakin tinggi pula kemampuan dan kesadaran mereka dalam menerima informasi.

Tingkat pengetahuan ibu hamil yang baik dipengaruhi oleh faktor pendidikan responden yang mayoritas berpendidikan menengah yaitu SMA/Sederajat $85,7 \%$ (30 responden). Menurut Mubarak (2011) tingkat pendidikan ikut menentukan mudah atau tidaknya seseorang menyerap dan memahami pengetahuan yang mereka peroleh, karena pada umumnya semakintinggi pendidikan seseorang maka semakin mudah penerimaan informasi. Hal ini didukung oleh hasil penelitian Anggraini (2014) yang menyimpulkan adanya hubungan antara tingkat pendidikan dengan pengetahuan tentang HIV/AIDS. Semakin tinggi pendidikan seseorang maka semakin baik pengetahuan tentang HIV/AIDS. Banyaknya responden yang memiliki pengetahuan yang baik tentang pemeriksaan screening HIV/AIDS padaibu hamil disebabkan karena seringnya petugas Kesehatan melakukan penyuluhan tentang hal tersebut baik pada saat pelayanan ANC maupun pada saat kelas ibu hamil. Demikian pula dengan media informasi (cetak dan elektronik), perkembangan media informasi yang cepat memudahkan ibu hamil untuk mendapatkan informasi tentang HIV/AIDS. ${ }^{9}$

Penelitian ini dapat disimpulkan bahwa pengetahuan ibu hamil tentang HIV/AIDS sangatlah penting karena akan mempengaruhi kesediaan atau minat ibu hamil untuk melakukan screening HIV/AIDS. Pengetahuan merupakan domain yang sangat penting untuk terbentuknya tindakan seseorang. Jika ibu memiliki pengetahuan yang baik tentang HIV/AIDS dan Tes HIV ibu akan lebih mudah untuk bersedia melakukan screening HIV. Hasil penelitian ini didukung juga oleh penjelasan Notoadmodjo bahwa pengetahuan merupakan strategi perubahan perilaku penting untuk menimbulkan kesadaran dan akhirnya berperilaku sesuai dengan pengetahuan yang dimilikinya $^{10}$

\section{KESIMPULAN}

Berdasarkan penelitian yang sudah dilakukan dapat disimpulkan bahwa ada hubungan antara pengetahuan ibu hamil tentang HIV/AIDS dengan keikutsertaan ibu hamil untuk melakukan screening HIV/AIDS. 


\section{KESIMPULAN}

Tulislah kesimpulan secara komprehensif, integratif, tanpa penomoran dan kualitatif (hindari menulis angka-angka hasil analisis data). Anda juga diizinkan menambahkan saran atau rekomendasi jika dipandang perlu.

\section{DAFTAR PUSTAKA}

1. Kemenkes RI. Pedoman Nasional Pencegahan HIV dari Ibu ke Anak (PPIA),2 ed. Jakarta: Badan Penelitian dan Pengembangan Kesehatan KemenkesRI.2012

2. Ditjen P2P Kemenkes RI. Laporan Perkembangan HIV AIDS dan PMS Triwulan IApril.

Dalamhttp://siha.depkes.go.id/portal/files_upl oad/Laporan_HIV_AIDS_TW_1_2017_rev.pd f. 2017

3. RSUD Cilacap. Data HIV/AIDS tahun 2018

4. Titik. Hubungan antara pengetahuan ibu hamil tentang HIV/AIDS dan VCT dengan sikap terhadap konseling dan tes HIV/AIDS secara sukarela di Puskesmas Karangdoro Semarang. Jurnal Kesehatan; 2011.

5. Notoatmodjo\& Soekidjo. Promosi kesehatan dan Perilaku Kesehatan. Jakarta: Rineka cipta. 2012

6. Hurlock, Elizabeth B. Psikologi PerkembanganSuatu Pendekatan Sepanjang Rentang Kehidupan. Jakarta: Erlangga.2011

7. Mubarak, W. I.Promosi Kesehatan untuk Kebidanan. Jakarta: Salemba Medika

8. Othman \& Samir, M. (2015). Knowledge About HIV/AIDS Among High School Students in Erbil City/Iraq. Jurnal Glob J Health $\quad$ Sci, $\quad$ V.7(1); $\quad 2015$ Jan.Dalamhttps://www.ncbi.nlm.nih.gov/pmc/ articles/PMC4796507/pdf/GJHS-7-16.pdf. 2011

9. Anggarini, I.G. Faktor-Faktor yang Mempengaruhi Perilaku Pemeriksaan VCT pada Ibu Hamil Di Wilayah Kerja Puskesmas II Melaya Kabupaten Jembrana Provinsi Bali.Skripsi. STIKes Ngudi Waluyo Ungaran. 2014

10. Dhenok \& Siti.. Faktor - Faktor Yang Berhubungan Dengan Pemanfaatan Program Prevention Of Mother To Child Transmission (PMTCT) Oleh Ibu Hamil Di Puskesmas Halmahera Kota Semarang. (http://jurnal .stikeskendedes.ac.id/index.php/KM J/article/view/49). 2016 